\title{
ENTOMOFAUNAL COMPARISON UNDER THREE LANDSCAPE CONDITIONS AT THE CERRO DE JUAICA (TENJO, CUNDINAMARCA)
}

\section{COMPARACIÓN DE LA FAUNA INSECTIL DE TRES PAISAJES EN EL CERRO DE JUAICA, MUNICIPIO DE TENJO, CUNDINAMARCA}

\author{
Andrés Mauricio Chaves Forero ${ }^{1}$, Héctor William Duarte Gómez ${ }^{2}$, Ingeborg Zenner de Polanía ${ }^{3}$
}

\begin{abstract}
${ }^{1}$ Ingeniero Agrónomo, Asesor independiente, e-mail: quercush@gmail.com; ${ }^{2}$ Ingeniero Agrónomo, M.Sc. Docente Investigador, Ingeniería Agronómica. Universidad de Ciencias Aplicadas y Ambientales U.D.C.A, calle 222 No. 57-30, Bogotá, D.C., Colombia, e-mail: wduarte@udca.edu.co; ${ }^{3}$ Ingeniera Agrónoma, M.Sc., Ph.D. Investigadora Universidad de Ciencias Aplicadas y Ambientales U.D.C.A, calle 222 No. 57-30, Bogotá, D.C., Colombia, e-mail: izenner@udca.edu.co; dirección para correspondencia
\end{abstract}

Rev. U.D.C.A Act. \& Div. Cient. 18(1): 127-136, Enero-Junio 2015

\section{SUMMARY}

Biodiversity studies of the insect fauna are scarce for high Andean forests in Colombia and absent for agroforestry systems. To contribute to the knowledge of this specific group in these ecosystems, a study was conducted to survey the diversity of the insect fauna present in the Juaica's hill at Tenjo, Cundinamarca. The ecosystem was divided into three landscapes: forest, agroforestry and pasture. Three native tree species were planted in the agroforestry system: oak (Quercus humboldtii), alder (Alnus acuminata) and magle or macle (Escallonia pendula) in order to observe their influence on the insect fauna diversity comparing it with the other two landscapes. In each landscape three insect capture techniques were employed per sampling site, arranged in transects: pitfall traps, sweep net and direct hand collection. During four months a total of 842 specimens were collected, represented by 87 insect morpho-species grouped into 49 families and 12 Orders. The Order of highest numerical importance was Diptera with 13 families, which corresponds to $26.5 \%$ of the abundance of the insect fauna, followed by Hemiptera with twelve families (25\%), Coleoptera with nine families (18\%), and Hymenoptera with five families (10\%). The analysis of the diversity indices, showed the highest value in rate for forest landscape with 3.50 for ShannonWiener and 11.17 for Margalef. The agroforestry system can be considered as a positive arrangement for either the maintenance or the establishment of an insect fauna, already absent in pasture which replaced the native forests.

Key words: Biodiversity, insect fauna, Andean forest, agroforestry system, pasture, diversity index.

\section{RESUMEN}

Los estudios de biodiversidad de la entomofauna son escasos para los bosques alto andinos en Colombia y ausentes para sistemas agroforestales. A fin de contribuir con el conocimiento de este grupo específico en estos ecosistemas, se realizó un estudio para conocer la diversidad de la entomofauna presente en el cerro de Juaica, en Tenjo, Cundinamarca. Este ecosistema, se dividió en tres paisajes, denominados bosque, sistema agroforestal y potrero. En el sistema agroforestal, se plantaron tres especies de árboles nativos: roble (Quercus humboldtii), aliso (Alnus acuminata) y magle o macle (Escallonia pendula), para observar su influencia respecto a la diversidad insectil, en comparación con el bosque nativo. En cada paisaje, se utilizaron tres técnicas de captura de insectos, por sitio de muestreo, distribuidos en transectos: trampas pitfall, red entomológica y colecta directa. Se colectaron 842 individuos durante cuatro meses, los cuales, se encuentran representados por 87 morfoespecies agrupadas en 49 familias y 12 Órdenes. El Orden de mayor importancia numérica fue Diptera, con 13 familias, que equivale al $26,5 \%$ de la abundancia de la entomofauna muestreada; le sigue Hemiptera, con doce familias (25\%); Coleoptera, con nueve familias (18\%) e Hymenoptera, con cinco familias (10\%). El análisis de los índices de diversidad mostró el valor más alto para el paisaje bosque, con 3,50, para Shannon-Wiener y 11,17, para Margalef. El sistema agroforestal se puede considerar como un arreglo positivo para el mantenimiento o el establecimiento de una fauna insectil, ya prácticamente ausente en los potreros, que reemplazaron el bosque.

Palabras clave: Biodiversidad, fauna insectil, bosque Andino, sistema agroforestal, potrero, índices de diversidad. 


\section{INTRODUCTION}

The growth of the agricultural sector in Latin America, under the use of conventional agricultural systems, is the source of degradation of natural resources, among which overgrazing, deforestation and biodiversity have been identified (FAO, 2007). Ruiz-Guerra et al. (2010), Laurance et al. (2007) and Rosensweig (2005) mention that fragmentation and habitat change are highlighted as the greatest threats to biodiversity. The fragmentation process interrupts the movement of herbivorous insect species, changes the relationships between organisms, and degrades or completely destroys the habitat (Savilaakso et al. 2009).

Insects, depending on the ecosystem and the measurement, comprise the most abundant animal group, inhabit many ecological niches and are considered essential for the dynamics of natural ecosystems; furthermore, they exhibit high sensitivity to anthropogenic interference and their composition reflects the stability performance of the ecosystem and represents the basis for the analysis of landscape structure (Fagundes et al. 2011; Thomazini \& Thomazini, 2000; Rosenberg et al. 1986).

To establish the richness and diversity of arthropods in ecosystems located at elevation higher than 2600masl, may help to recognize their function in various ecological processes, among which stand out herbivory and pollination (Amat \& Vargas, 1991). However, surveys of insects and other arthropods are scarce in high Andean ecosystems, moor (paramo) and sub-paramo. The most complete study published to date, covering species of all insect Orders was made in the "Entrenubes" Park, an area associated with the eastern hills that surround Bogotá (Departamento Técnico Administrativo del Medio Ambiente Corporación SUNA HISCA. s.f.). Other contributions to the knowledge of some insect Orders of the high mountains were made by Andrade \& Amat (1996), Sturm \& Rangel (1995), Salamanca \& Chamorro (1995) and Amat \& Vargas (1991).

The detection and monitoring of changes in the local fauna between undisturbed and disturbed ecosystems is important to determine the impact of human activities on biodiversity (Phillips et al. 2006). Arthropods, including insects, correspond to the dominant taxa in forest ecosystems, have a high potential as indicators of habitat changes, and are also useful for recovery studies and are increasingly used in conservation studies (McGeoch, 1998). For this reason, among others, families such as Carabidae and Staphylinidae of Coleoptera, Formicidae (Hymenoptera), butterflies (Lepidoptera), have been used (Luo et al. 2013; Yu et al. 2009; Bergmann et al. 2012; de Almeira Soares et al. 2010; Ribeiro-Troian et al. 2009; Andrade, 1998).
Agroforestry is considered a sustainable land management practice that increases its overall productivity, combining crop production, including forestry, and forest plants and / or animals, simultaneously or sequentially on the same land unit (Jiménez \& Muschler, 2001). Originally, the implementation of agroforestry systems was considered a very important alternative to carbon sequestration in the tropics (CassanovaLugo et al. 2011), but now it emerges also as a positive contributor to maintain and enhance biodiversity, primarily arthropods. Bhagwat et al. (2008) compared the arthropod species richness and composition in tropical forest reserves and agroforestry systems, concluding that agroforestry can help preserve a high proportion of tropical biodiversity, under current pressure for land use; so, according to the same authors agroforestry is an approach not only for the management of natural resources but also of biodiversity conservation in tropical areas.

Furthermore, Bichier (2006) concluded that agroforestry provides sustainable conditions, important for buffer zones between protected areas; agroforestry systems can be seen as an extension of natural habitats that can be managed according to the need of man.

Biodiversity assessments may provide information for conducting research later on, such as monitoring work in order to detect medium and long term changes or studies for the management of natural resources (Sánchez \& Sánchez, 2004).

Based on the need to obtain more information about the entomofaunal diversity, the present study sought to characterize the diversity of insect communities under three landscape conditions: high Andean forest, agroforestry system, and pasture, located at Juaica hill, municipality of Tenjo, Cundinamarca, Colombia.

\section{MATERIALS Y METHODS}

The research was carried out in the municipality of Tenjo, located at latitude north 04'53'58.92 and longitude 74'7'26.37' west at an altitude ranging between 2714 and 2765masl, in the village of Juaica, at the border zone of high Andean forest and the "sub paramo" (sub-moor).

Evaluated landscapes: The insect sampling was conducted on: high Andean forest, agroforestry system and pasture. The forest landscape did not undergo any transformation due to human interference during the study, while the agroforestry system was established; no grazing was allowed in the pasture areas.

The forest area is characterized by its ample vegetative biodiversity, standing out mainly shrubs, small trees, herbaceous 
plants, epiphytes and cryptogams with abundant presence of mosses and lichens (Figure 1).
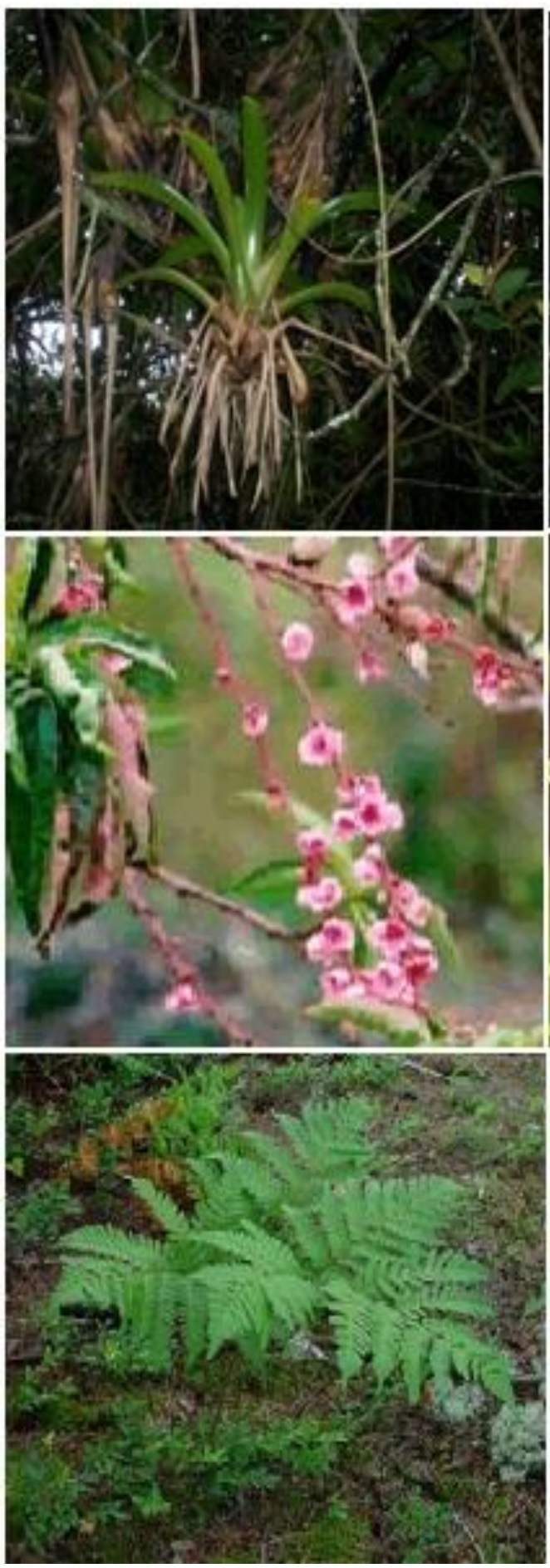

The agroforestry and pasture areas were located adjacent to the forest site. At the agroforestry site oak Quercus humboldtii Bonpland (Fagaceae), alder, Alnus acuminata
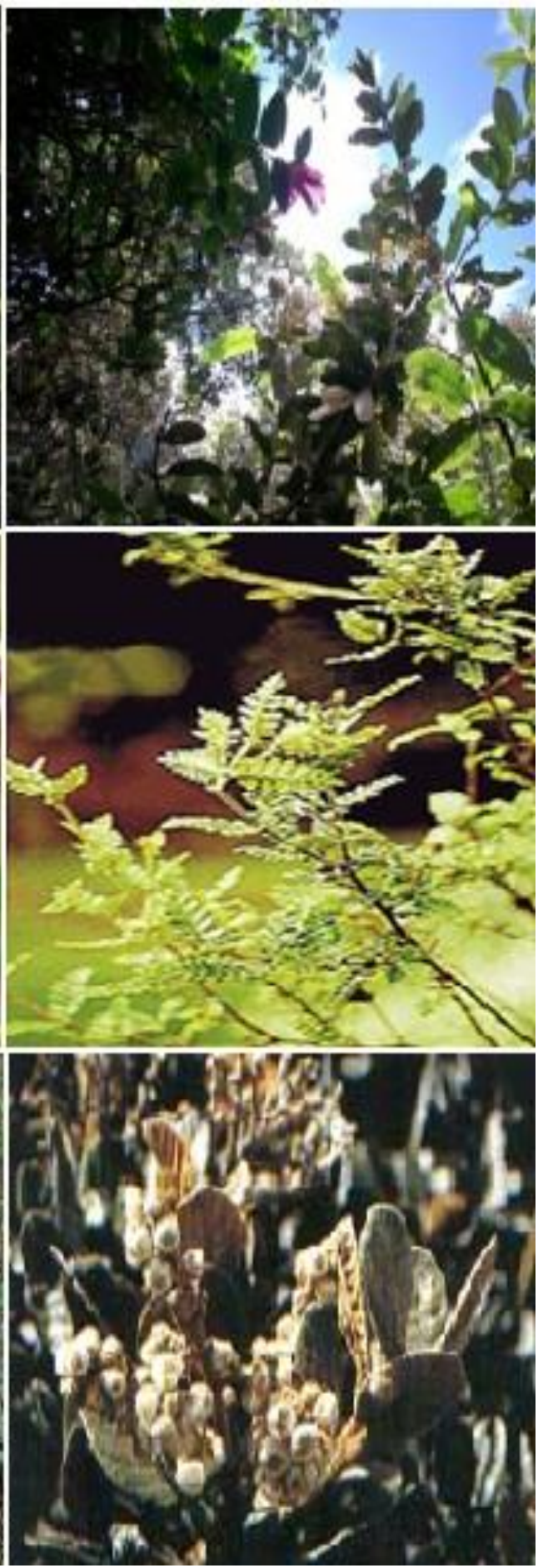

Figure 1. Native vegetation present at the cerro de Juaica. From left to right: a bromelia, quiche (Guzmania sp.), Andean shrub, pegamosco (Befaria resinosa), capulí, raque (Vallea stipularis), encenillo (Weinmannia tomentosa), pig fern, helecho marrano (Pteridium aquilinum), saffron, azafrán (Clethra fimbriata). 
HBK (Betulaceae) and magle or macle, Escallonia pendula (Ruiz \& Pav.) Pers. (Escalloniaceae) were established. These tree species were chosen because they are native trees that once dominated these territories, however, their existence is prone to extinction, due to the increment of the rural population and the agricultural development and livestock production (Pérez-Arbeláez, 1956).

The pasture site was dominated by Festuca sp. (Poaceae) and herbs such as dandelion, Taraxacum officinale (Asteraceae), nightshade, Solanum nigrum (Solanaceae), red clover, Trifolium pratense (Fabaceae), as well as some small unidentified legumes. Some shrubs of wild blackberry, Rubus floribundus (Rosaceae) were also present at this site. This area did not suffer alterations during the present study, since no additional plant species were sown, nor was grazing allowed.

Sampling: A $120 \mathrm{~m}$ long transect was established in each site and in each five sampling stations, separated $30 \mathrm{~m}$, were marked. At each station, sampling was performed by installing one pitfall trap, making seven double sweep net passes and by direct collection during 15 minutes, with an entomological aspirator and manually in logs, on soil and stems of trees, at the site where these plants were available. Four samplings were conducted monthly, separated by seven days. The pitfall traps consisted of glass bottles $13 \mathrm{~cm}$ high by $5.5 \mathrm{~cm}$ in diameter, half filled with a solution of soapy water (Harwood, 2008; Beanland et al. 2006; Isard et al. 2000).

Specimen identification: The insects were identified in the laboratory of entomology at the University of Applied Environmental Sciences U.D.C.A. Under a stereoscope the specimens were identified to the family level using Johnson \& Borror (2005) taxonomic keys. In this study the identification beyond family was not considered. Morpho-species (msp) within each family were grouped based on visual observations of the morphological characteristics under the stereoscope. In this way it was possible to define the existence of the same morpho-species in the three environments. For Diptera and Hymenoptera the identification was accomplished by removing their wings and mounting them on platelets for observation.

The collected specimens were preserved in $70 \%$ alcohol. The butterflies were stored in paper envelopes.

A representative sample of the collected material was mounted and deposited in the U.D.C.A's entomological reference collection.

Data analysis: The following variables for each sample were used: number of specimens, class, Order, family, morphospecies, month and site. The Shannon-Wiener and Margalef biodiversity indices were calculated using the PAST program (0.45).

\section{RESULTS AND DISCUSSION}

At the 15 sampling stations 842 individuals were collected; 291 specimens in the agroforestry landscape, in high Andean forest 235 and 316 in the pasture site. The diversity of the insect fauna was represented by 87 morpho-species, grouped into 49 families and 12 Orders (Table 1). The morpho-species recorded in this study represent a $60 \%$ of the total species richness estimated for the high Andean forests that surround the Bogotá plateau which correspond to 150 according to the study presented by Andrade \& Amat (2000).

Diptera was the Order with highest abundance divided within 13 families and 19 morpho-species, followed by Coleoptera nine families and 18 morpho-species, Hemiptera twelve families and 20 morpho-species, Hymenoptera five families and 15 morpho-species. Lepidoptera contributed with three families and six morpho-species. Orthoptera presented two families and four morpho-species. The remaining orders Odonata, Dermaptera, Blattaria, Phasmatodea and Thysanoptera participated each with one family and one morpho-species.

Although there are no publications that would have enabled an accurate comparison with our results, it is interesting to point out that in the Entrenubes Park study (DTAMA, s.f.), the Order with the greatest abundance was also Coleoptera, followed by Hymenoptera and Lepidoptera. But other studies in similar landscapes have found that the highest abundance was obtained for Diptera followed by Coleoptera at the moor "La Parada del Viento" (Morales-Castaño \& Amat-Garcia, 2012).

The most common families in the three environments were Carabidae, Curculionidae, Ichneumonidae, Apidae, Vespidae, Muscidae, Syrphidae, Nymphalidae, Miridae, Cicadellidae and Acridiae. Among the families that harbor beneficial insects, specimens of Carabidae were absent at the pasture site, Syrphidae were collected in the three environments, while members of Vespidae were absent in the agroforestry system. Parasitoids of the family Ichneumonidae were abundant in the three biotypes. These bio-controllers can count on abundant prey and hosts, represented by the adults, larva and nymphs of the other families.

In table 1, the diversity of families and morpho-species shared between environments can be observed. In the forest and agroforestry their diversity is not significantly different, while, the richness within the pasture site was reduced (Table 2). The similarity between forest and agroforestry supports the theory, previously mentioned, of the benefit of agroforestry 
Table 1: Landscape distribution of orders, families and morpho-species. A.F.S: agroforestry system; F.: high Andean forest, P.: pasture.

\begin{tabular}{|c|c|c|c|c|c|}
\hline \multirow{2}{*}{ ORDER } & \multirow{2}{*}{ FAMILY } & \multirow{2}{*}{$\begin{array}{l}\text { Mopho-spe- } \\
\text { cies }\end{array}$} & \multicolumn{3}{|c|}{ LANDSCAPE } \\
\hline & & & A.F.S & F. & P. \\
\hline Blattaria & Blattidae & 1 & $\mathbf{x}$ & $\mathbf{x}$ & $\mathbf{x}$ \\
\hline \multirow{18}{*}{ Coleoptera } & \multirow{3}{*}{ Carabidae } & 1 & $\mathrm{x}$ & $\mathbf{x}$ & \\
\hline & & 2 & & $\mathrm{x}$ & \\
\hline & & 3 & & $\mathrm{x}$ & \\
\hline & \multirow{2}{*}{ Chrysomelidae } & 1 & $\mathbf{x}$ & $\mathrm{x}$ & \\
\hline & & 2 & $\mathbf{x}$ & & \\
\hline & \multirow{2}{*}{ Cleridae } & 1 & $\mathbf{x}$ & $\mathbf{x}$ & $\mathbf{x}$ \\
\hline & & 2 & & $\mathbf{x}$ & \\
\hline & \multirow{2}{*}{ Coccinellidae } & 1 & $\mathbf{x}$ & $\mathbf{x}$ & $\mathbf{x}$ \\
\hline & & 2 & $\mathbf{x}$ & & \\
\hline & \multirow{3}{*}{ Curculionidae } & 1 & & $\mathrm{x}$ & \\
\hline & & 2 & $\mathrm{x}$ & $\mathrm{x}$ & \\
\hline & & 3 & $\mathrm{x}$ & $\mathrm{x}$ & \\
\hline & Lycidae & 1 & $\mathrm{x}$ & $\mathbf{x}$ & \\
\hline & \multirow{2}{*}{ Melolonthidae } & 1 & $\mathbf{x}$ & & \\
\hline & & 2 & $\mathbf{x}$ & & \\
\hline & \multirow{2}{*}{ Scarabaeidae } & 1 & $\mathbf{x}$ & $\mathbf{x}$ & $\mathbf{x}$ \\
\hline & & 1 & & & $\mathbf{x}$ \\
\hline & Staphylinidae & 1 & $\mathrm{x}$ & $\mathbf{x}$ & \\
\hline Dermaptera & Forficulidae & 1 & $\mathbf{x}$ & $\mathbf{x}$ & \\
\hline \multirow{15}{*}{ Hymenoptera } & Braconidae & 1 & $\mathrm{x}$ & $\mathbf{x}$ & $\mathbf{x}$ \\
\hline & \multirow{4}{*}{ Ichneumonidae } & 1 & $\mathrm{x}$ & $\mathrm{x}$ & $\mathbf{x}$ \\
\hline & & 2 & $\mathbf{x}$ & $\mathbf{x}$ & $\mathbf{x}$ \\
\hline & & 3 & $\mathrm{x}$ & & \\
\hline & & 4 & & $\mathbf{x}$ & $\mathbf{x}$ \\
\hline & \multirow{6}{*}{ Apidae } & 1 & & $\mathrm{x}$ & \\
\hline & & 2 & $\mathrm{x}$ & $\mathrm{x}$ & \\
\hline & & 3 & $\mathrm{x}$ & & $\mathbf{x}$ \\
\hline & & 4 & $\mathbf{x}$ & $\mathbf{x}$ & \\
\hline & & 5 & $\mathbf{x}$ & $\mathbf{x}$ & \\
\hline & & 6 & $\mathbf{x}$ & & \\
\hline & \multirow{3}{*}{ Vespidae } & 1 & & $\mathrm{x}$ & $\mathbf{x}$ \\
\hline & & 2 & & $\mathbf{x}$ & $\mathbf{x}$ \\
\hline & & 3 & & & $\mathbf{x}$ \\
\hline & Formicidae & 1 & $\mathbf{x}$ & & $\mathbf{x}$ \\
\hline \multirow{11}{*}{ Diptera } & Bibionidae & 1 & $\mathbf{x}$ & & $\mathbf{x}$ \\
\hline & Culicidae & 1 & $\mathbf{x}$ & $\mathrm{x}$ & $\mathbf{x}$ \\
\hline & Dolichopodidae & 1 & $\mathbf{x}$ & $\mathbf{x}$ & $\mathbf{x}$ \\
\hline & Drosophilidae & 1 & $\mathbf{x}$ & $\mathbf{x}$ & $\mathbf{x}$ \\
\hline & \multirow{2}{*}{ Empididae } & 1 & $\mathrm{x}$ & $\mathbf{x}$ & $\mathbf{x}$ \\
\hline & & 2 & $\mathbf{x}$ & $\mathbf{x}$ & $\mathbf{x}$ \\
\hline & \multirow{3}{*}{ Muscidae } & 1 & $\mathrm{x}$ & & $\mathbf{x}$ \\
\hline & & 2 & $\mathrm{x}$ & & $\mathbf{x}$ \\
\hline & & 3 & $\mathbf{x}$ & & $\mathbf{x}$ \\
\hline & Phoridae & 1 & $\mathrm{x}$ & $\mathrm{x}$ & \\
\hline & Piophilidae & 1 & & $\mathbf{x}$ & \\
\hline
\end{tabular}


Continuation Table 1.

\begin{tabular}{|c|c|c|c|c|c|}
\hline \multirow{8}{*}{ Diptera } & Pipunculidae & 1 & & & $\mathbf{x}$ \\
\hline & \multirow{3}{*}{ Syrphidae } & 1 & $\mathbf{x}$ & $\mathbf{x}$ & $\mathbf{x}$ \\
\hline & & 2 & $\mathbf{x}$ & & $\mathbf{x}$ \\
\hline & & 3 & $\mathbf{x}$ & & \\
\hline & Tabanidae & 1 & & & $\mathbf{x}$ \\
\hline & \multirow[t]{2}{*}{ Tachinidae } & 1 & $\mathbf{x}$ & & \\
\hline & & 2 & $\mathbf{x}$ & & \\
\hline & Tipulidae & 1 & & $\mathbf{x}$ & $\mathbf{x}$ \\
\hline \multirow{6}{*}{ Lepidoptera } & Hesperiidae & 1 & $\mathbf{x}$ & $\mathbf{x}$ & \\
\hline & \multirow{3}{*}{ Nymphalidae } & 1 & $\mathbf{x}$ & $\mathbf{x}$ & \\
\hline & & 3 & $\mathbf{x}$ & $\mathbf{x}$ & \\
\hline & & 3 & & $\mathbf{x}$ & \\
\hline & \multirow[t]{2}{*}{ Pieridae } & 1 & $\mathbf{x}$ & $\mathbf{x}$ & $\mathbf{x}$ \\
\hline & & 2 & $\mathbf{x}$ & $\mathbf{x}$ & $\mathbf{x}$ \\
\hline \multirow{20}{*}{ Hemiptera } & Berytidae & 1 & $\mathbf{x}$ & $\mathbf{x}$ & $\mathbf{x}$ \\
\hline & Coreidae & 1 & $\mathbf{x}$ & $\mathbf{x}$ & \\
\hline & \multirow[t]{2}{*}{ Largidae } & 1 & & $\mathbf{x}$ & \\
\hline & & 2 & $\mathbf{x}$ & $\mathbf{x}$ & \\
\hline & \multirow[t]{2}{*}{ Lygaeidae } & 1 & & $\mathbf{x}$ & \\
\hline & & 2 & $\mathbf{x}$ & $\mathbf{x}$ & \\
\hline & \multirow{3}{*}{ Miridae } & 1 & & $\mathbf{x}$ & \\
\hline & & 2 & $\mathbf{x}$ & $\mathbf{x}$ & $\mathbf{x}$ \\
\hline & & 3 & $\mathbf{x}$ & & \\
\hline & Pentatomidae & 1 & $\mathbf{x}$ & & $\mathbf{x}$ \\
\hline & Reduviidae & 1 & & $\mathbf{x}$ & \\
\hline & Tingidae & 1 & & $\mathbf{x}$ & \\
\hline & \multirow[t]{2}{*}{ Cercopidae } & 1 & $\mathbf{x}$ & & $\mathbf{x}$ \\
\hline & & 2 & & & $\mathbf{x}$ \\
\hline & Cicadellidae & 1 & $\mathbf{x}$ & $\mathbf{x}$ & $\mathbf{x}$ \\
\hline & & 2 & $\mathrm{x}$ & $\mathbf{x}$ & $\mathbf{x}$ \\
\hline & & 3 & $\mathbf{x}$ & & $\mathbf{x}$ \\
\hline & Cicadidae & 1 & $\mathbf{x}$ & $\mathbf{x}$ & \\
\hline & Membracidae & 1 & $\mathbf{x}$ & $\mathbf{x}$ & \\
\hline & & 2 & $\mathbf{x}$ & $\mathbf{x}$ & \\
\hline Odonata & Aeschnidae & 1 & & $\mathbf{x}$ & \\
\hline \multirow{4}{*}{ Orthoptera } & \multirow{3}{*}{ Acrididae } & 1 & $\mathbf{x}$ & $\mathbf{x}$ & $\mathbf{x}$ \\
\hline & & 2 & $\mathbf{x}$ & $\mathbf{x}$ & $\mathbf{x}$ \\
\hline & & 3 & $\mathbf{x}$ & $\mathbf{x}$ & \\
\hline & Gryllacrididae & 1 & $\mathbf{x}$ & & \\
\hline Phasmatodea & Phasmidae & 1 & $\mathbf{x}$ & $\mathbf{x}$ & \\
\hline Thysanoptera & Thripidae & 1 & & & $\mathbf{x}$ \\
\hline
\end{tabular}


Table 2. Number of insect families and morpho-species present in the three landscapes.

\begin{tabular}{|c|c|c|}
\hline Landscape & No. Families & No. Morpho-species \\
\hline High Andean forest & 40 & 60 \\
\hline Agroforestry System & 40 & 63 \\
\hline Pasture & 27 & 41 \\
\hline
\end{tabular}

systems to mitigate the destruction of habitat due to the conversion of forests into pastures (Bhagwat et al. 2008).

Shannon-Wiener and Margalef diversity indices presented values in the forest site of 3.50 and 11.17 , respectively. However, the agroforestry landscape had similar values 3.39 (Shannon-Wiener) and 11.1 (Margalef). The lowest values were recorded in the pasture landscape with 2.66 (Shannon) and 6.95 (Margalef). According to Margalef (1981), many ecosystems showing a lower diversity compared to the estimated undisturbed can be seen in invading ecosystems, corresponding to what we found in the pasture site in this study.

There is an equal representation of families in the different landscapes; some families exist in the high Andean forest and the agroforestry landscapes, some in the forest and pasture and others in pasture and agroforestry. Figure 2 shows the presence of families in each of the landscapes in the study area. The insect families collected in all of the three landscapes are equivalent to the $35 \%$ of the sampled family richness. The interaction forest-agroforestry system share 15 families, representing $31 \%$ of the total family richness. The presence of families within the forest and the pasture landscape was of only two-families Tipulidae and Vespidae, equivalent to $4 \%$, while the share of families in the interaction agroforestry system-pasture was five, representing $10 \%$ of the total family richness. This relatively high percentage can be explained by the existence of grasses within the agroforestry system.

Based on this result, it is concluded that the implemented agroforestry system can be considered as a reservoir of insect biodiversity provided that is adjacent to a natural forest. This system could provide support for native plants and insects associated with them that depend on the forest habitat.

There is an increasing interest in the search for suitable agroforestry systems for conservation purposes (Monge \& Russo, 2009; Bichier, 2006). The results of the present study indicate that the artificially established agroforestry system landscape was beneficial for the existence of the insect fauna; showing a high presence of families (40) and morpho-species (63). Furthermore, it shared 15 families with the forest landscape, equivalent to $31 \%$ of the total family richness, compared with the pasture landscape which shared only five families, equivalent to $10 \%$ of the total families collected. The beneficial impact of the agroforestry system can be attributed to the fact that the planted tree species in this site may have met the insect's requirements for their development; harboring insects, food for other species, generating shadow and also providing protection and attraction for predatory insects. It could be assumed that agroforestry systems, within small forest areas can also serve as biological corridors, that facilitate the movement of insects and other animals, birds, reptiles, mammals; issue to be studied and tested through other long term research.

From this research it can be concluded that agro-forestry provides valuable natural habitat for many wild plants and animals, including possibly some endangered species. This type of system could possibly prevent the extinction of some species, especially in regions where little natural forest is left, due to its replacement by pasture.

The results of this research conducted in three different landscapes of the Cerro de Juaica, should provide a basic and preliminary idea about the composition of their insect fauna. Specific studies aimed to understand the structure of arthropod communities in high mountain environments have to be performed, and compared with studies to be developed in other similar geographic regions. Research that may address the current state of arthropod communities inhabiting high Andean forests and surrounding areas, may serve to monitor and recognize threaten species.

Finally, it is considered that the richness of the insect fauna found in the Cerro de Juaica is largely due to the diversity of microhabitats present in the different landscapes and vegetation. The preliminary estimate of 87 morpho-species is a reflection of indicative value in terms of the abundance of insects in these environments and their numerous specializations towards ecological niches.

Acknowledgements: to the inhabitants of the surroundings of the Cerro Juaica and dignitaries of the municipality of Tenjo, Cundinamarca, Colombia. Conflict of interests: The manuscript was prepared and reviewed with the participation of all authors, who declare that no conflict of interest that could jeopardize the validity of the results presented exists. 


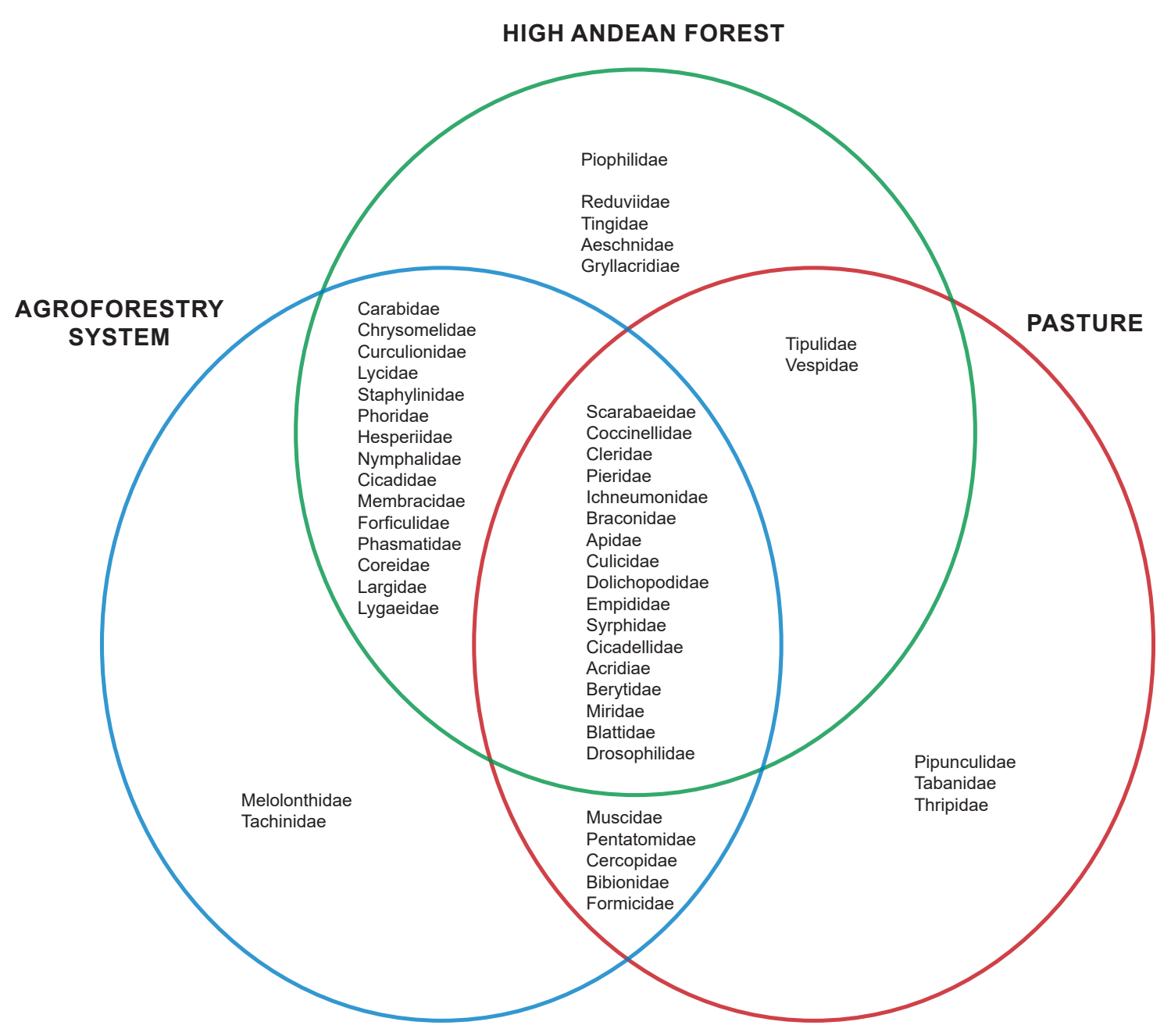

Figura 2. Insect family inter-action within the three landscapes.

\section{BIBLIOGRAPHY}

1. AMAT, G.; VARGAS, O. 1991. Caracterización de microhábitats de la artropofauna en páramos el Parque Nacional Natural Chingaza, Cundinamarca, Colombia. Caldasia. 16(79):539-550.

2. ANDRADE, M.G.; AMAT, G. 2000. Guía preliminar de insectos de Santafé de Bogotá y sus alrededores. Departamento Técnico Administrativo Medio Ambiente. Alcaldía Mayor de Santafé de Santa Fe de Bogotá. 95p.

3. ANDRADE, M.G. 1998. Utilización de las mariposas como bioindicadoras del tipo de hábitat y su diversidad en Colombia. Rev. Acad. Col. Cienc. Físicas, Exactas y Naturales. 22(84):407-421.
4. ANDRADE, M.G.; AMAT, G. 1996. Un estudio regional de las mariposas altoandinas de la Cordillera Oriental de Colombia. En: Andrade, M.G.; Amat, G.; Fernández, F. (eds). Insectos de Colombia. Estudios escogidos. Vol I. Academia Colombiana de Ciencias Físicas, Exactas y Naturales. Centro Editorial Javeriano (CEJA). 541p.

5. BEANLAND, L.A.; NOBLE, R.; WOLF, T.K. 2006. Spatial and temporal distribution of North American grapevine yellows disease and of potential vectors of the causal Phytoplasmas in Virginia. Environ. Entomol. 35(2):332-344.

6. BICHIER, P. 2006. La Agroforestería y el Mantenimiento de la Biodiversidad. ActionBioscience.org. Disponible desde Internet en http://www.actionbioscience.org/ esp/biodiversidad/bichier.html (con acceso 07/10/14). 
7. BHAGWAT, S.A.; WILLIS, K.J.; BIRKS, H.J.B.; WHITTAKER, R.J. 2008. Agroforestry: a refuge for tropical biodiversity? Trends Ecol. Evol. 23(5):261-268.

8. BERGMANN, D.J.; BRANDENBURG, D.; PETIT, S.; GABEL, M. 2012. Habitat preference of ground beetle (Coleoptera: Carabidae) species in the northern Black Hills of South Dakota. Environ. Entomol. 41(5):1069-1076.

9. CASSANOVA-LUGO, F.; PETIT-ALDANA, J.; SOLORIOSÁNCHEZ, J. 2011. Los sistemas agroforestales como alternativa a la captura de carbono en el trópico mexicano. Rev. Chapingo Serie Ciencias Forestales y del Ambiente. 17(1):133-143.

10. DE ALMEIRA SOARES, S.; ANTONIALLI-JUNIOR, W.F.; LIMA-JUNIOR, S.E. 2010. Diversidades de formigas epigéicos (Hymenoptera: Formicidae) em dos ambientes no Centro-Oeste do Brasil. Rev. Bras. Entomol. 54(1):76-81.

11. DEPARTAMENTO TÉCNICO ADMINISTRATIVO DEL MEDIO AMBIENTE CORPORACIÓN SUNA HISCA. DTAMA. s.f. Entomofauna. Asesoría técnica agroambiental para la apropiación y consolidación del parque ecológico distrital Entrenubes a partir de la formulación del plan de ordenamiento y manejo. Tomo I, Capítulo 14. Inventario preliminar asociado al Parque Entrenubes: una aproximación a su diagnóstico ambiental. p.I-398-I-426. Disponible desde Internet en: http://www.sentidonatural.org/Publicaciones $\% 20 \mathrm{HJ} /$ Entomofauna\%20Parque\%20Entrenubes.pdf (con acceso 15/11/2014).

12. FAGUNDES, C.K.; DI MARE, R.A.; WINK, C.; MANFIO, D. 2011. Diversity of the families of Coleoptera captured with pitfall traps in five different environments in Santa Maria, RS, Brazil. Braz. J. Biol. 71(2):381390.

13. FAO. 2007. El estado mundial de la agricultura y la alimentación. Pagos a los agricultores por servicios ambientales. Agricultura -38. Organización de las Naciones Unidas para la Agricultura y Alimentación. Roma. 255p.

14. HARWOOD, J.D. 2008. Are sweep net sampling and pitfall trapping compatible with molecular analysis of predation? Environ. Entomol. 37(4):990-995.

15. ISARD, S.A.; SPENCER J.L.; NASSER, M.A.; ELI LEVINE, E. 2000. Aerial movement of Western Corn Root- worm (Coleoptera: Chrysomelidae): Diel periodicity of flight activity in soybean fields. Environ. Entomol. 29(2):226-234.

16. JIMÉNEZ, F.; MUSCHLER, R. 2001. Introducción a la agroforestería. Funciones y aplicaciones de sistemas agroforestales. Módulos de Enseñanza Agroforestal CATIE/GTZ. p.1-24.

17. JOHNSON, N.F.; BORROR, D.J. 2005. Borror and DeLong's Introduction to the Study of Insects. 7 ed. Thompson Brooks/Cole. 864p.

18. LAURANCE, W.F.; NASCIMENTO, H.E.M.; LAURANCE, S.G.; ANDRADE, A.; EWERS, R.M.; HARMS, K.E.; LUIZAO, R.C.C.; RIBEIRO, J.E. 2007. Habitat fragmentation, variable edge effects and the landscape divergence hypothesis. PLoS ONE 2: e1017.

19. LUO, T.-H.; YU, X.-D.; ZHOU, H.-Z. 2013. Effects of reforestation practices on Staphylinid beetles (Coleoptera: Staphylinidae) in southwestern China forests. Environ. Entomol. 42(1):7-16.

20. MARGALEF, R. 1981. Ecología. Barcelona, Editorial Planeta. 252p.

21. McGEOCH, M, 1998. The selection, testing and application of terrestrial insects as bioindicators. Biol. Rev. 73:181-201.

22. MONGE, J.; RUSSO, R. 2009. Agroforestería, sostenibilidad y biodiversidad. 2009. 1a ed. - Guácimo, Costa Rica. Editorial EARTH. p.4-11.

23. MORALES-CASTAÑO, I.T.; AMAT-GARCÍA, G.D. 2012. Diversidad de la artropofauna terrestre del páramo la Parada del Viento, cordillera oriental, CundinamarcaColombia. Bol. Soc. Entomol. (S.E.A.). 51:211-216.

24. PÉREZ-ARBELÁEZ, E. 1956. Plantas útiles de Colombia. $3^{a}$ redacción, Sucesores de Rivadeneyra, S.A. Madrid. 831p.

25. PHILLIPS, I.D.; COBB, T.P.; SPENCE, J.R.; BRIGHAM, R.M. 2006. Salvage lodging, edge effects, and carabid beetles; connections to conservation and sustainable forest management. Environ. Entomol. 35:950-957.

26. RIBEIRO-TROIAN, V.R.; BALDISSERA, R.; HARTZ, S.M. 2009. Effects of understory structure and the abundance, richness and diversity of Collembola (Arthropoda) in southern Brazil. Neotrop. Entomol. 38(3):340-345. 
27. ROSENBERG, D.M.; DANKS, H.V.; LEHMKUHL, D.M. 1986. Importance of insects in environmental impact assessment. Environ. Managem. 10(6):773-783.

28. ROSENSWEIG, M.L. 2005. Avoiding mass extinction: basic and applied challenges. Am. Midland Naturalist. 153:195-208.

29. RUIZ-GUERRA, B.; GUEVARA, R.; MARIANO, N.A.; DIRZO, R. 2010. Insect herbivory declines with forest fragmentation and covaries with plant regeneration mode: evidence from a Mexican tropical rain forest. Oikos. 119:317-325.

30. SÁNCHEZ, F.; SÁNCHEZ, P. 2004. Inventario de mamíferos en un bosque de los Andes centrales de Colombia. Caldasia. 26(1):291-309.

31. SALAMANCA, N.; CHAMORRO, C. 1995. La edafofauna del páramo de Monserrate - Sector Hacienda "Santa Barbara" - (Cundinamarca, Colombia). En: Mora Osejo, L.E.; Sturm, H. (eds). Estudios ecológicos del páramo y del bosque altoandino. Cordillera Oriental de Colombia. Tomo I. Academia Colombiana de Ciencias Fisicas, Exactas y Naturales. Colección Jorge Álvarez Lleras. No. 6.
32. SAVILAAKSO, S.; KOIVISTO, J.; VETELI, T.O.; PUSENIUS, J.; ROININEN, H. 2009. Long lasting impact of forest harvesting on the diversity of herbivorous insects. Biodiv. Conserv. 18:3931-3948.

33. STURM, H.; RANGEL, O. 1995. Consideraciones sobre la vegetación, la productividad primaria neta y la artropofauna asociada en regiones paramunas de la Cordillera Oriental. En: Mora Osejo, L.E.; Sturm, H. (eds). Estudios ecológicos del páramo y del bosque altoandino. Cordillera Oriental de Colombia. Tomo I. Academia Colombiana de Ciencias Físicas, Exactas y Naturales.Colección Jorge Álvarez Lleras. No. 6.

34. THOMAZINI, M.J.; THOMAZINI, A.P.B.W. 2000. A fragmentação florestal e a diversidades de insectos nas florestas tropicais úmidas. Rio Branco: Embrapa Acre. 21p.

35. YU, X.-D.; LUO, T.-H.; ZHOU, H.-Z. 2009. Distribution of carabid beetles (Coleoptera: Carabidae) across ecotones between regenerating and mature forests in southwestern China. Environ. Entomol. 38(4):10531060.

Recibido: Noviembre 20 de 2014

Aceptado: Abril 11 de 2015

How to cite (Cómo citar):

Chaves Forero, A.M.; Duarte Gómez, H.W.; Zenner de Polanía, I. 2015. Entomofaunal comparison under three landscape conditions at the cerro de Juaica (Tenjo, Cundinamarca). Rev. U.D.C.A Act. \& Div. Cient. 18(1): 127-136. 